УДК 666.1.002.5

В.В. Буличов /к.т.н./,

С.В. Швачич /к.ф.-м.н./,

А.В. Гаврилко

ДВНЗ «Український державний хімікотехнологічний університет», м. Дніпро, Україна

\title{
РОЗРОБКА ЕНЕРГОЗБЕРІГАЮЧИХ ЗАХОДІВ ЩОДО ТЕПЛОВОЇ РОБОТИ СКЛОВАРНОЇ ПЕЧІ НА ОСНОВІ ОБЧИСЛЮВАЛЬНИХ ЕКСПЕРИМЕНТІВ
}

V.V. Bulychov/Cand. Sci. (Tech.)/,

S.V.Shvachich /Cand. Sci. (Phys.-Math.)/, A.V.Havrylko
DHEI "Ukrainian State University of Chemical Technology", Dnipro, Ukraine

\section{DEVELOPMENT OF EPNON-SAVING ACTIVITIES ON THE HEAT OPERATION OF A GLASS FURNACE BASED ON THE COMPARISON OF EXPERIMENTS}

Мета. Метою роботи є розробка енергозберігаючих засобів щьоо теплової роботи скловарної печі.

Методика. Дослідження теплової роботи конкретної скловарної печі виконувалось шляхом математичного моделювання її теплового балансу з подальшим аналізом. На основі иього запропоновані на основі обчислювальних експериментів енергозберігаючі засоби.

Результати. Зроблено порівняльний розрахунок трубчатих рекуператорів. Для утилізачіі теплоти димових газів з метою вибору більш ефективного методу вирішена задача оптимізаціі з отриманням оптимальних температур, а саме: температур шихти та склобою та температури повітря. Мінімальна витрата палива складає $13,7 \mathrm{~m}^{3} / \mathrm{c}$ при оптимальних температурах: нагрітого повітря $1164{ }^{\circ} \mathrm{C}$ та шихти і склобою $-143{ }^{\circ} \mathrm{C}$, з чого випливає, щяо в цих умовах витрата палива зменшується на 23,8\% від базової.

Наукова новизна. Розроблена математична модель теплової роботи конкретної скловарної печі, представлена рівнянням теплового балансу, адекватним уявленням про теплофізичні процеси промислового скловаріння і результатам їх експериментального дослідження, розроблені відповідні енергозберігаючі заходи.

Практична цінність. За результатами досліджень може бути розрахована ефективність роботи регенерачї̈ тепла скловарної печі.

Ключові слова: скловарна піч, шихта, витрата палива, скловаріння, енергозберігаючі заходи, ефективність використання палива.

DOI: $10.34185 / 0543-5749.2019-5-6-27-31$

В умовах ринкової економіки випуск конкурентоспроможної продукції на вітчизняних промислових підприємствах пов'язаний з необхідністю зниження енергоємності виробництва, так як споживання енергії на одиницю продукції в Україні в півтора-два рази вище, ніж в індустріально розвинених країнах. Ця обставина свідчить про необхідність вирішення актуальних завдань енергозбереження, що визначено одним із пріоритетних напрямків державної політики України.

Промисловий теплотехнологічний комплекс $є$ одним з основних споживачів матеріальних i паливно-енергетичних ресурсів в Україні. Тільки одні високотемпературні теплотехнологічні системи 3 паливними промисловими печами за рівнем споживання палива конкурують 3 тепловими електростанціями.

(C) Буличов В.В., Швачич С.В., Гаврилко А.В., 2019 
Скляне виробництво відноситься до числа найбільш енергоємних. Основна частина скла на підприємствах проводиться в ванних регенеративних печах безперервної дії, які характеризуються великою різноманітністю конструктивних і режимних параметрів. Через значні втрати теплоти ККД агрегатів становить близько 20 $25 \%$, а питома витрата теплоти на виробництво скловиробів може становити від 7,5 до 45 ГДж/т.

3 огляду на значну енергоємність виробництва скла на підприємствах України, високу вартість природного газу і вогнетривів, підвищення ефективності роботи промислових агрегатів виробництва скла $є$ актуальним завданням, що має велике практичне значення.

Перспективними напрямками досліджень щодо зниження енергоспоживання на підприємствах скляної промисловості на думку фахівців є:

- розробка і впровадження нових технічних рішень 3 енергозбереження при проектуванні технологічних ліній;

- розробка і впровадження поточних і перспективних заходів 3 енергозбереження;

- впровадження енергетичного менеджменту на підприємствах [1].

При модернізації діючих та при проектуванні нових пічних установок i агрегатів для промислового виробництва скловиробів практичні завдання енергозбереження можуть вирішуватися за такими напрямками:

- реконструкція скловарних печей 3 комплексним використанням прогресивних технічних рішень в конструкції печі, способів генерації теплової енергії, охолодження і теплової ізоляції найбільш відповідальних конструктивних елементів;

- удосконалення процесу спалювання шляхом розробки ефективних паливо-спалюючих пристроїв;

- раціонального використання вторинних енергоресурсів в системі регенерації печей і в системах теплоенергопостачання підприємств;

- створення принципово нових технологічних агрегатів [2].

Скло являє собою штучний матеріал, який отримують шляхом переохолодження розплаву незалежно від його хімічного складу і температурної області затвердіння, володіє такими властивостями, як прозорість, твердість, хімічна стійкість, термостійкість.

Надзвичайно різні вимоги до виробів зі скла, з одного боку, та різноманітні властивості його як матеріалу, з іншого, зумовили розробку чисельних технологічних процесів, способів та устаткування дозволяють отримати широкий асортимент виробів - від листкового скла, скляної тари, посуду, оптичного та кварцового скла, і нових кристалічних матеріалів [3].

Ці різні процеси та засоби отримання скловиробів зажадали розробки скловарних печей різного типу, що відрізняються не тільки своєю конструкцією, продуктивністю, але і режимами варіння скла $[3,4]$.

Скловарні печі займають особливе місце не тільки за шириною їх застосування, різноманітності типів, конструктивних схем і режимів теплової роботи, але і по складності протікання в них тепло технологічних процесів, що в підсумку призводить до їх досить низької теплової ефективності $[3,4]$.

Дивлячись на ці обставини існують великі можливості розробки заходів та технічних рішень по вдосконаленню високотемпературної тепло технологічної установки, враховуючи, що тепловий коефіцієнт корисної дії скловарних печей в даний час, як правило, не перевищує $15-35 \%$. Тому в цій роботі будуть розглянуті заходи щодо вдосконалення теплової роботи скловарної печі на основі обчислювальних експериментів.

Вирішення задач енергозбереження в промислових високотемпературних тепло технологічних комплексах при виробництві скломаси може бути реалізована за умови застосування системного аналізу в процесі розгляду тепло технологічного ланцюга виробництва скломаси [3, 4].

Але також не варто забувати про окремі заходи 3 енергозбереження, оскільки вони дають можливість розглянути конкретний процес (агрегат) і отримати більш точну інформацію при аналізі окремих об'єктів, ніж при загальному аналізі, тому далі розглянемо окремі заходи, щодо поліпшення теплової роботи печі.

Для розробки енергозберігаючих заходів розглянемо конкретну скловарну піч з наступними вихідними даними (табл. 1). Розрахуємо також іï тепловий баланс 3 подальшим аналізом. $[5]:$

Рівняння теплового балансу печі має вигляд

$$
Q_{1}+Q_{2}=Q_{3}+Q_{4}+Q_{5}+Q_{6}+Q_{7}+Q_{8}+Q_{9},
$$

де $Q_{1}$ - хімічна теплота палива, кВт; $Q_{2}-$ фізична теплота підігрітого повітря, кВт; $Q_{3}-$ теплота, яка необхідна на процеси утворення скломаси, кВт; $Q_{4}$ - теплота 3 відхідними димовими газами, кВт; $Q_{5}-$ втрати 3 випромінюванням, кВт; $Q_{6}-$ втрати на нагрів зворотних потоків скломаси, кВт; $Q_{7}$ - втрати в навколишнє середовище через кладку печі, кВт; $Q_{8}-$ втрати 3 
газами через нещільності у кладці печі, кВт; $Q_{9}$ - неврахований тепловий потік, кВт.
Результати розрахунку теплового балансу зводимо у табл. 2.

Таблиця 1. Вихідні данні

\begin{tabular}{|c|c|c|c|c|}
\hline № & Назва параметру & Одиниці вимірювання & Позначення & Величина \\
\hline 1 & Теплотворна здатність палива & 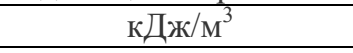 & $Q_{H}$ & 33077,3 \\
\hline 2 & Діаметр пальника & MM & $d$ & 25 \\
\hline 3 & Тиск газу перед пальником & кге $/ \mathrm{cm}^{2}$ & $\mathrm{P}_{2}$ & 0,4 \\
\hline 4 & Кількість пальників & шт & $n n$ & $2 \times 2$ \\
\hline 5 & Продуктивність печі & Кг/ч & G & 900 \\
\hline 6 & Температура у варильний зоні & ${ }^{\circ} \mathrm{C}$ & $t_{6}$ & 1530 \\
\hline 7 & Температура у виробничій зоні & ${ }^{\circ} \mathrm{C}$ & $t_{p}$ & 1290 \\
\hline 8 & Тиск у печі & мм.рт.ст. & $P$ & 9 \\
\hline 9 & Температура перед димовою трубою & ${ }^{\circ} \mathrm{C}$ & $t_{m p}$ & 470 \\
\hline 10 & Температура підігрітого повітря & ${ }^{\circ} \mathrm{C}$ & $t_{n B}$ & 1032 \\
\hline 11 & Температура димових газів & ${ }^{\circ} \mathrm{C}$ & $t_{\partial}$ & 1216 \\
\hline 12 & Коефіцієнт надлишку повітря & - & $\alpha$ & 1,43 \\
\hline 13 & Витрата повітря для горіння 1 м $^{3}$ палива & $\mathrm{M}^{3} / \mathrm{M}^{3}$ & $V_{B}$ & 13,7 \\
\hline 14 & Об’єм димових газів на 1 м³ палива & $\mathrm{M}^{3} / \mathrm{M}^{3}$ & $V_{\partial}$ & 14,7 \\
\hline 15 & Температура повітря & ${ }^{\circ} \mathrm{C}$ & $t_{0}$ & 20 \\
\hline 16 & Питома витрата тепла на варіння 1 кг скломаси & кДж/кг & $n$ & 2930 \\
\hline \multirow[t]{5}{*}{17} & Коефіцієнт діафрагмування: & & & \\
\hline & влетів & - & $\varphi_{1}$ & 0,8 \\
\hline & загрузочного карману & - & $\varphi_{2}$ & 0,5 \\
\hline & екрану печі & - & $\varphi_{3}$ & 0,4 \\
\hline & відкритих отворів & - & $\varphi_{4}$ & 0,6 \\
\hline
\end{tabular}

Таблиця 2. Тепловий баланс

\begin{tabular}{|c|c|c|c|c|c|}
\hline \multirow{2}{*}{$\begin{array}{l}\text { Прихід } \\
\text { теплоти }\end{array}$} & \multicolumn{2}{|c|}{ Кількість теплоти } & \multirow{2}{*}{$\begin{array}{l}\text { Витрати } \\
\text { теплоти }\end{array}$} & \multicolumn{2}{|c|}{ Кількість теплоти } \\
\hline & кBт & $\%$ & & кВт & $\%$ \\
\hline $\begin{array}{l}\text { Хімічна теплота } \\
\text { палива, } Q_{1}\end{array}$ & 5953,91 & 55,97 & На процеси утворення скломаси, $Q_{3}$ & 732,5 & 6,87 \\
\hline \multirow{6}{*}{$\begin{array}{l}\text { Фізична теплота } \\
\text { повітря, } Q_{2}\end{array}$} & \multirow[t]{6}{*}{4682,38} & \multirow[t]{6}{*}{44,03} & Тепло з відхідними газами, $Q_{4}$ & 4767,12 & 44,68 \\
\hline & & & Втрати з випромінюванням, $Q_{5}$ & 726,71 & 6,81 \\
\hline & & & $\begin{array}{l}\text { Втрати на нагрів зворотних потоків } \\
\text { скломаси, } Q_{6}\end{array}$ & 189 & 1,77 \\
\hline & & & Втрати в навколишнє середовище, $Q_{7}$ & 2871,2 & 26,91 \\
\hline & & & Втрати з газами через нещільності, $Q_{8}$ & 319 & 2,99 \\
\hline & & & Неврахований тепловий потік, $Q_{9}$ & 1063,63 & 9,97 \\
\hline Сума & 10636,29 & 100,00 & & 10669,16 & 100,00 \\
\hline
\end{tabular}

КПД печі: $\eta=Q_{3} /\left(B \cdot Q_{H}\right)=12,3 \%$.

В результаті проведеного обстеження 3 використанням паспортних даних i розрахунку теплового балансу встановлено основні теплотехнічні показники роботи скловарної печі. Слід відзначати низьку ефективність роботи агрегату, ККД печі складає 12,3 \%, що пояснюється високим рівнем теплових втрат з відхідними газами і через огородження печі, ці втрати становлять 44,68 і 26,91 \% відповідно. Причому такі великі теплові втрати 3 газами пояснюються, насамперед, високим значенням температури газів за регенератором $470-510^{\circ} \mathrm{C}$. також не слід забувати про інші недоліки, такі як неврахований тепловий потік $Q_{9}$, втрати становлять $9,97 \%$, втрати випромінюванням $Q_{5}-$ $6,81 \%$, щоб їх зменшити треба використовувати різні обмазки, вогнетривкі маси та штукатурки вогнетривів, для стійкості від високих температур застосовувати різні види охолоджень вогнетривів.

Далі розглянемо декілька заходів для поліпшення теплової роботи теплової печі. А саме: зробимо порівняльний розрахунок сталевого та чавунного трубчастих рекуператорів для утилізації теплоти димових газів. Вихідні дані для проведення розрахунку приведені в табл. 3. 
Таблиця 3. Вихідні данні

\begin{tabular}{|l|c|}
\hline Температура повітря $t_{\boldsymbol{B}},{ }^{\circ} \mathrm{C}$ & 20 \\
\hline Температура повітря на виході із рекуператора $t_{b}^{\prime},{ }^{\circ} \mathrm{C}$ & 300 \\
\hline Температура ваграночних (відхідних) газів на вході в рекуператор $t_{\partial},{ }^{\circ} \mathrm{C}$ & 1216 \\
\hline
\end{tabular}

В результаті розрахунків отримали, що для підігріву зовнішнього повітря від 20 до $300^{\circ} \mathrm{C}$ знадобилася різна площа рекуператорів, для чавунного вона складає 238,06 м², для сталевого $147,16 \mathrm{~m}^{2}$ :

$$
\Delta F=F_{\psi}-F_{c m}=90,9 \mathrm{M}^{2}
$$

Тобто при однаковому нагріві повітря у сталевого рекуператора знадобилася менша поверхня тепло сприймання.
3 метою визначення мінімально можливої витрати палива в умовах розглянутої печі вирішена задача оптимізації з отриманням оптимальних температур, а саме: температур шихти та склобою та температури повітря, що нагрівається. Математична модель базувалась на рівнянні теплового балансу, приведеному вище. Для вирішення задачі оптимізації був обраний метод сканування. Результати розрахунків представлені на рис. 1 .

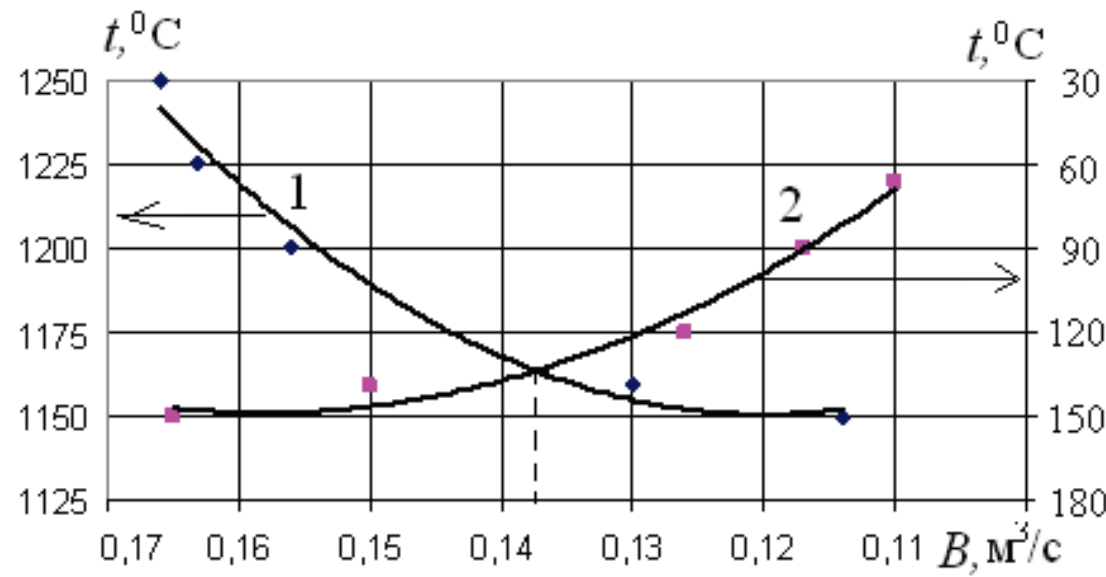

Рис. 1. Залежність температури нагрітого повітря (1) та температури шихти і склобою (2) від витрати палива

Мінімальна витрата палива складає $13,7 \mathrm{~m}^{3} / \mathrm{c}$ при оптимальних температурах: нагрітого повітря $-1164{ }^{\circ} \mathrm{C}$ та шихти і склобою $-143{ }^{\circ} \mathrm{C}$, $з$ чого випливає, що в цих умовах витрата палива зменшується на 23,89\% від базової.

Висновки. У даній роботі були розглянуті та реалізовані шляхи оптимізації теплової роботи конкретної скловарної печі. А саме: запропонована установка рекуператора в конвективний тракт печі, розрахована його теплообмінна поверхня. Методами математичного моделювання визначені оптимальні температури шихти i склобою з одного боку та температури нагрітого повітря 3 іншого, що дозволило скоротити витрати палива.

Бібліографічний список

1. Кошельник В. М., Долженко Е. Ю., Кошельник А. В., Ивановский А. Ю. Экономиче- ская эффективность внедрения энергосберегающих мероприятий для стекловаренных печей. Вестник Харьковского государственного политехнического университета. 1998. Вып. 13. C. 33-36.

2. Системный поход к решению задач энергосбережения в промышленных высокотемпературных теплотехнологических комплексах / Ю. М. Мацевитый и др. Проблемы ииностроения. 2004. № 3-4. С. 43-52.

3. Воробьев Х. С., Мазуров Д. Я., Соколов А. А. Теплотехнологические процессы и аппараты силикатных производств. Москва : Высшая школа, 1965. 356 с.

4. Панкова Н. А., Михайленко Н. Ю. Теория и практика промышленного стекловарения : учебное пособие. Москва : РХТУ им. Д.И. Менделеева, 2000. 102 с.

5. Кафаров В. В., Глебов М. Б. Математиче- 
ское моделирование основных процессов химических производств. Москва: Высшая школа, 1991.

\section{References}

1. Koshelnik V. M., Dolzhenko E. Iu., Koshelnik A. V., \& Ivanovskii A. Iu. (1998). Ehkonomicheskaia ehffektivnost vnedreniia ehnergosberegaiushchikh meropriiatii dlia steklovarennykh pechei. Vestnik Kharkovskogo gosudarstvennogo politekhnicheskogo universiteta, 13.

2. Yu.M. Macevitij et al. (2004). Sistemnij podhod $\mathrm{k}$ resheniuy zadach energosberegeniya $\mathrm{V}$ promishlennih visokotemperaturnih teplotehnologicheskih kompleksah. Problemi shinostroeniya, (34).

3. Vorobiev, H. C., Mazurov, D. Ya., \& Sokolov, A. A. (1965). Teplotehnologicheskie processi $i$ apparati silikatnih proizvodstv. Moskva : Visshaya shkola.

4. Pankova, N. A., \& Mihajlenko, N. Yu. (2000). Teoriya s praktika promishlennogo steklovareniya. Moskva: RHTU im. D.I. Mendeleeva.

5. Kafarov, V. V., \& Glebov, M. B. (1991). Matematicheskoe modelirovanie osnovnykh protsessov khimicheskikh proizvodstv. Moskva: Vysshaia shkola.

Цель. Целью работь является разработка энергосберегающих средств по тепловой работе стекловаренной печи.

Методика. Исследование тепловой работь конкретной стекловаренной печи выполнялось путем математического моделирования ее теплового баланса с последующим анализом. На основе этого предложены на основе вычислительных экспериментов энергосберегаюшиче средства.

Результать. Сделан сравнительньй расчет трубчатых рекуператоров. Для утилизации теплоты дымовых газов с иелью выбора более эффективного метода решена задача оптимизации с получением оптимальных температур, а именно: температур иихты и стеклобоя $и$ температуры воздуха. Минимальный расход топлива составляет 13,7 м $^{3} /$ с при оптимальных mемпературах: нагретого воздуха $1164{ }^{\circ} \mathrm{C} u$ иихты и стеклобоя - $143{ }^{\circ} \mathrm{C}$, из чего следует, что в этих условиях расход топлива уменьшается на 23,8\% от базовой.

Научная новизна. Разработана матема- тическая модель тепловой работы конкретной стекловаренной печи, представленная уравнением теплового баланса, адекватным представлением о теплофизических прочессах промышленного стекловарения и результатах их экспериментального исследования, разработаны соответствующие энергосберегающие мероприятия.

Практическая ценность. По результатам исследований может быть рассчитана эффективность работь регенерации тепла стекловаренной печи.

Ключевые слова: стекловарная печь, шихта, расход топлива, стекловарения, энергосберегаюшие мероприятия, эффективность использования топлива.

Purpose. The purpose of the work is the development of energy-saving means for the thermal operation of the glass furnace.

Methods. The study of the thermal performance of a particular glass furnace was performed by mathematical modeling of its thermal balance with subsequent analysis. According to this, energysaving means are proposed based on computational experiments.

Results. A comparative calculation of tubular recuperators is made. To recycle flue gas heat and select more efficient method the optimization problem with obtaining the optimum temperatures has been solved, namely: charge and hatch temperatures and air temperature. The minimum fuel consumption is $13.7 \mathrm{~m}^{3} / \mathrm{s}$ at optimum temperatures: heated air $1164{ }^{\circ} \mathrm{C}$ and charge and glass $-143^{\circ} \mathrm{C}$, which implies that in these conditions, the fuel consumption is reduced by $23.8 \%$ from the base.

Originality. The mathematical model of thermal work of a particular glassmaking furnace is developed, presented by the heat balance equation, an adequate idea of the thermophysical processes of industrial glassmaking and the results of their experimental research, and the corresponding energysaving measures are developed.

Practical implications. According to the results of the research, the efficiency of the heat recovery of the glass furnace can be calculated.

Key words: glass furnace, charge, fuel consumption, glass melting, energy-saving measures, fuel efficiency.

Рукопис надійшов 06.11.2019 